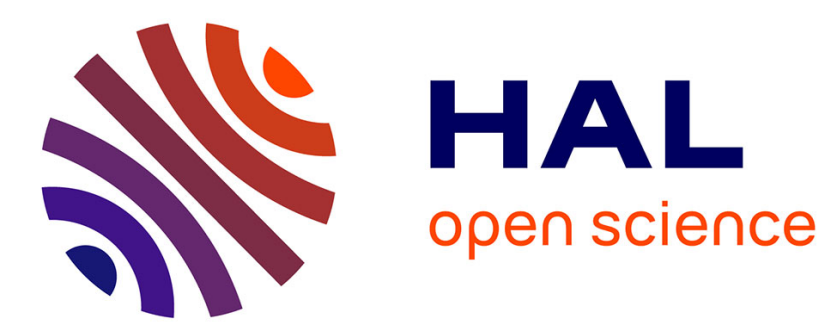

\title{
Efficiency measures and productivity indexes in the context of university library benchmarking
}

\author{
Gerhard Reichmann, Margit Sommersguter-Reichmann
}

\section{To cite this version:}

Gerhard Reichmann, Margit Sommersguter-Reichmann. Efficiency measures and productivity indexes in the context of university library benchmarking. Applied Economics, 2009, 42 (03), pp.311-323. 10.1080/00036840701604511 . hal-00582221

\section{HAL Id: hal-00582221 \\ https://hal.science/hal-00582221}

Submitted on 1 Apr 2011

HAL is a multi-disciplinary open access archive for the deposit and dissemination of scientific research documents, whether they are published or not. The documents may come from teaching and research institutions in France or abroad, or from public or private research centers.
L'archive ouverte pluridisciplinaire HAL, est destinée au dépôt et à la diffusion de documents scientifiques de niveau recherche, publiés ou non, émanant des établissements d'enseignement et de recherche français ou étrangers, des laboratoires publics ou privés. 


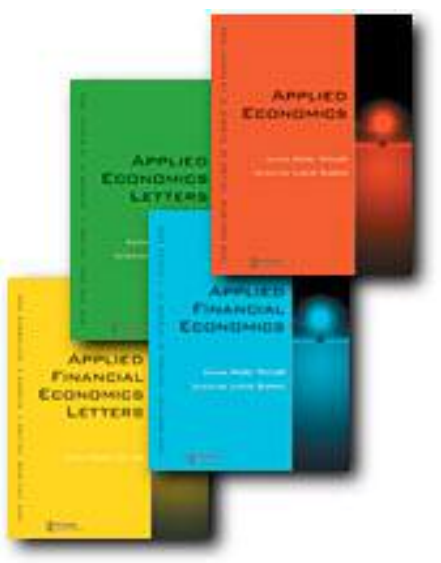

Efficiency measures and productivity indexes in the context of university library benchmarking

\begin{tabular}{|r|l|}
\hline Journal: & Applied Economics \\
\hline Manuscript ID: & APE-07-0075.R1 \\
\hline Journal Selection: & Applied Economics \\
\hline Date Submitted by the \\
Author: & 26-Jul-2007 \\
\hline Complete List of Authors: & $\begin{array}{l}\text { Reichmann, Gerhard; Graz University, Department of Information } \\
\text { Science and Information Systems } \\
\text { Sommersguter-Reichmann, Margit; Graz University, Department of } \\
\text { Finance }\end{array}$ \\
\hline JEL Code: & $\begin{array}{l}\text { C61 - Optimization Techniques|Programming Models|Dynamic } \\
\text { Analysis \&lt; C6 - Mathematical Methods and Programming \&lt; C - } \\
\text { Mathematical and Quantitative Methods, L31 - Nonprofit Institutions } \\
\text { Industrial Organization }\end{array}$ \\
\hline Keywords: & $\begin{array}{l}\text { Data Envelopment Analysis, Library efficiency, Environmental } \\
\text { influence }\end{array}$ \\
\hline
\end{tabular}

\section{๑scholarONE" \\ Manuscript Central}




\title{
Efficiency measures and productivity indexes in the
}

\section{context of university library benchmarking}

\author{
Gerhard Reichmann, Margit Sommersguter-Reichmann* \\ Graz University, Department of Information Science and Information Sys- \\ tems/Department of Finance, Universitaetsstraße 15, 8010 Graz, Austria. \\ E-mail: gerhard.reichmann@uni-graz.at, margit.sommersguter@uni-graz.at
}

Running title: Library efficiency measures and productivity indexes

\section{Abstract}

Data Envelopment Analysis (DEA) has attracted considerable attention during the last few decades as an intuitively clear method for performance assessment. Theoretical developments have taken turns with empirical efficiency studies. In this paper we empirically analyse performance differences across university libraries from different countries from a cross-section and a longitudinal perspective. We use the Malmquist index approach to disentangle environmental efficiency from technical efficiency to highlight performance differences eventually induced by environmental factors beyond the control of library management, as well as to decompose productivity changes over time into changes in technical efficiency and changes in technology. In our cross-section analysis we found that North American libraries are more productive at higher input levels than the European libraries from Germany and Austria at which we looked in this contribution. Moreover, the largest North American libraries are still able to improve performance, as the results of panel data analysis revealed.

\footnotetext{
* Corresponding author
} 


\section{Efficiency measures and productivity indexes in the context of university library benchmarking}

\section{Introduction}

There are numerous theoretical and empirical papers on the subject of benchmarking in general and university-related benchmarking in particular. Benchmarking usually consists of several steps: First, the initiation process, which comprises the definition of the research question and the choice of the methodology; second, the data gathering process, which covers data collection as well as data screening; third, the processing of the data and the interpretation of results, including - if necessary - some sensitivity analysis; fourth, the implementation of strategies derived from the benchmarking, and fifth, the monitoring process where the implementation of strategies is under current surveillance (see e.g. Fischer et al (2003)).

In this contribution benchmarking is interpreted as a performance comparison across organisations (over time) where the organisations are university libraries from different countries. Performance is given a productivity interpretation, defined as the output produced by the library (i.e. archival and utilisation services) given their available input (i.e. current and capital resources). Presumably, libraries perform differently, with some libraries being 'best practice' performers and others doing worse. 'Best practice' libraries are those with the highest output-toinput ratio (i.e. productivity) compared to the other libraries in the sample. Causes for performance differences, however, can be found in management decisions but also in environmental factors beyond the control of the library management. 
The purpose of this contribution is to extend previous empirical research by revealing performance differentials across university libraries from different countries over time. To solve the problems of conflicting results when multiple performance indicators (i.e. multiple output-input-ratios) are used, we apply Data Envelopment Analysis (DEA) (see e.g. Zhu (2003) or Cook and Zhu (2005)) to investigate library performance. Using DEA, we can take into consideration that the library service production process is characterised by multiple inputs and multiple outputs, and also distinguish between performance differences resulting from managerial factors and those resulting from factors beyond the control of library management. Assessing the performance of university libraries from different countries over a time period of six years, we then try to reveal productivity differences across different library groups as well as the productivity changes over time of individual libraries.

Accordingly, the paper is organised as follows: The next two sections provide an overview of previous work on the subject of university library benchmarking, the methodological approach, the sample and data. The fourth section provides the results and gives possible interpretations of performance differences. Limitations of the current analysis are discussed and an outlook is given in the last section.

\section{Previous studies}

For more than 20 years, libraries have been confronted with performance comparisons. Numerous publications deal with the theoretical development of performance indicators to cover the libraries' range of activities (e.g. Moore (1989), Poll and Boekhorst (1996), Brophy (1989), Ceynowa (2001), Crawford et al. 
(1998), Mundt and Guschker (2003) and Van House et al. (1990)). Other publications concentrate on the empirical assessment of library performance. Many authors use established performance indicators, such as the number of circulations per student or the number of requests processed per employee, with the main disadvantage being that each performance indicator only covers partial performance. Berghaus-Sprengel (2001) discussed the limits of benchmarking against the background of using multiple performance indicators in empirically assessing performance of university libraries.

Recently, several studies have attempted to derive an aggregate performance indicator based on the analysis of the overall performance of university libraries. From a methodological point of view many authors fell back on DEA: Chen (1997) compared Taiwanese university libraries, Kao and Lin (1999) particularly investigated the effect of library size on library performance, Kao and Liu (2000) addressed the problem of missing data in DEA-based performance assessment. Shim and Kantor (1998) and Shim $(2000,2003)$ provided an overview of the possibilities of DEA for library benchmarking. They discussed in detail the strengths and weaknesses of DEA in the context of library performance evaluation, thereby covering the fundamental problems of finding suitable input and output indicators. Reichmann (2004) and Reichmann and Sommersguter-Reichmann (2006) addressed the problems of differing environments and their effects on library performance. Vitaliano (1998) and Worthington (1999) analysed the performance of public libraries in New York (Vitaliano) and New South Wales, Australia (Worthington).

While DEA interprets any deviation from an empirically-derived frontier as inefficiency, frontier deviations in stochastic frontier analysis (SFA) are decomposed 
into an inefficiency and an error term. Some recent studies using SFA to assess library performance can be found in Saunders (2003) and Hemmeter (2006). A methodological discussion of stochastic and non-stochastic frontier estimation is given in Fried et al. (1993), a critical comment on frontier techniques in general is provided by Smith and Street (2005).

\section{Methodology}

\subsection{Performance assessment using DEA}

DEA belongs to the 'enveloping techniques', dating back to the work of Farrell (1957), and was further developed and popularised by Charnes et al. (1978) who introduced the term 'Data Envelopment Analysis' into the scientific literature. The concept of DEA is founded on the comparison of actual with best observed productivity, where productivity is measured as the proportion of services produced to inputs used. DEA can handle multiple inputs and outputs without requiring information on input and output prices.

Meanwhile, DEA has become a well-accepted tool for performance assessment, especially in the non-profit sector (see, for example, Fizel and Nunnikhoven (1993), Glass et al. (1998), Mizala et al. (2002), Hammond (2002), Ouellette and Vierstraete (2005), Grosskopf et al. (2006) and Worthington and Dollery (2002)).

Using DEA we assess overall university library performance, comprising the analysis of productivity differences from a cross-section as well as a longitudinal perspective. 


\subsubsection{Cross section analysis}

Assume that there are $j=1, \ldots, k, \ldots, n$ units, where each unit produces $r=1, \ldots, s$ outputs $y_{r}$ using $i=1, \ldots, m$ inputs $x_{i}$. Analytically, most DEA models require the solution of a linear program (LP) which might be of the following form ${ }^{1}$ :

$\frac{1}{T E_{k}}=\max _{\eta, \lambda} \eta_{k}$

subject to

$\sum_{j=1}^{n} x_{i j} \lambda_{j} \leq x_{i k} \quad \forall i=1, \ldots, m$

$\sum_{j=1}^{n} y_{r j} \lambda_{j} \geq y_{r k} \eta_{k} \quad \forall r=1, \ldots, s$

$\sum_{j=1}^{n} \lambda_{j}=1$

$\lambda_{j} \geq 0 \quad \forall j=1, \ldots, n \quad$ and $\eta_{k} \ldots$ free

LP (1)-(5) measures output-based technical efficiency, TE, indicating whether or not the maximum output given the input is produced (i.e. TE=1 indicates efficient, $T E<1$ inefficient services production). ${ }^{2}$ The use of an output-oriented DEA model is justified by the fact that libraries are mainly confronted with the claim of output control given their budgets. The convexity constraint $\sum \lambda_{j}=1$ characterises the best practice technology as a variable returns-to-scale (RTS) technology which is chosen as we are only interested in identifying efficiency differences attributable

\footnotetext{
${ }_{2}^{1}$ LP (1)-(5) corresponds to the model proposed by Banker et al. in 1984.

2 In contrast to this output-augmenting efficiency measure, an input-conserving efficiency measure may also be derived. For detailed information on different DEA models see e.g. Cooper et al. (2000), Coelli et al. (1999), Thanassoulis (2001), Zhu (2003) or Cook and Zhu (2005).
} 
to managerial decisions. The investigation of other sources of inefficiency, such as scale (identifying suboptimal library size) or allocative efficiency (identifying the suboptimal factor mix given factor prices) are beyond the scope of this contribution.

Against the background of assessing performance differentials across university libraries located in different countries we have to take into consideration the possibility of environmental influences on efficiency. As we will see later in this article, we have two different environments, the North American (NA) and the European (EU) $)^{1}$ environment.

There have been several approaches to account for non-identical environments, ranging from one-stage models where environmental variables are directly included in the DEA model (see e.g. Banker and Morey (1986a, b)), two-stage approaches where only discretionary inputs and outputs are included in the DEA model and variations (in efficiency scores or slacks) are then explained in a second-stage regression analysis (see e.g. Fried et al. (1993)) to three-stage models where both producer performance, environmental differences and statistical noise are accounted for (see Fried et al. (2002)).

Another possibility of disentangling environmental and technical efficiency is to use the approach proposed by Charnes et al. (1981). Using this approach library efficiency is measured relative to its environment-specific frontier first. Next, all libraries are rendered pareto-efficient and pooled together so that environmental efficiency is calculated as the distance of technically efficient libraries to a so-

\footnotetext{
${ }^{1}$ In this contribution we look at university libraries from two European countries with comparable environments: Germany and Austria. For details see section 3.2.1.
} 
called grand frontier. As this approach might be criticised due to assuming both separate frontiers and a common frontier we apply the Malmquist index approach $^{1}$ (hereafter called the MI approach) to assess productivity differences due to environmental effects.

Using the Ml approach we estimate productivity differences due to environmental effects based on the distance between group-specific frontiers only. The outputoriented MI based on reference technology e is calculated by

$M I_{o}^{e}\left(y^{2}, x^{2}, y^{1}, x^{1}\right)=\frac{T E_{o}^{e}\left(y^{2}, x^{2}\right)}{T E_{o}^{e}\left(y^{1}, x^{1}\right)}$

with

$T E_{o}^{e}$ being output technical efficiency relative to the technology prevailing in environment $e$.

According to Färe et al. (1992) this index can be further decomposed, in this case into a technical efficiency index (TEI) and an environmental efficiency index (EEI):

$$
M I_{o}^{e}\left(y^{2}, x^{2}, y^{1}, x^{1}\right)=\frac{T E_{o}^{e}\left(y^{2}, x^{2}\right)}{T E_{o}^{e}\left(y^{1}, x^{1}\right)}=\underbrace{\frac{T E_{o}^{2}\left(y^{2}, x^{2}\right)}{T E_{o}^{1}\left(y^{1}, x^{1}\right)}}_{\text {TEI }} \cdot \underbrace{\frac{T E_{o}^{e}\left(y^{2}, x^{2}\right) / T E_{o}^{2}\left(y^{2}, x^{2}\right)}{T E_{o}^{e}\left(y^{1}, x^{1}\right) / T E_{o}^{1}\left(y^{1}, x^{1}\right)}}_{\text {EEI }} .
$$

Using the MI to disentangle managerial (technical) from environmental efficiency, it is necessary to choose a reference environment e and units which shall be compared in pairs. In contrast to using the $\mathrm{MI}$ in the context of longitudinal analysis where we compare each library's performance over time it is not obvious

\footnotetext{
${ }^{1}$ See Malmquist (1953) and Färe et al. (1998).
} 
which libraries to choose for comparison in cross section analysis when the comparison groups consist of different libraries. Following Berg et al. (1993), p. 376 et seq., we assess environmentally-induced efficiency differences by comparing the smallest, the largest and the average ${ }^{1}$ library (measured in full-time equivalent staff) of one group with the smallest, largest and average library of the other group. As the choice of the reference technology may also have an impact on the results we both use the NA and the EU environment as reference technology.

Consequently, using the NA frontier as reference, the $\mathrm{Ml}$ is calculated as:

$$
\begin{aligned}
M I_{o}^{N A}\left(y^{N A}, x^{N A}, y^{E U}, x^{E U}\right)= & \frac{T E_{o}^{N A}\left(y^{N A}, x^{N A}\right)}{T E_{o}^{N A}\left(y^{E U}, x^{E U}\right)}= \\
& \frac{T E_{o}^{N A}\left(y^{N A}, x^{N A}\right)}{T E_{o}^{E U}\left(y^{E U}, x^{E U}\right)} \cdot \frac{T E_{o}^{N A}\left(y^{N A}, x^{N A}\right) / T E_{o}^{N A}\left(y^{N A}, x^{N A}\right)}{T E_{o}^{N A}\left(y^{E U}, x^{E U}\right) / T E_{o}^{E U}\left(y^{E U}, x^{E U}\right)}
\end{aligned}
$$

which reduces to

$$
M I_{o}^{N A}\left(y^{N A}, x^{N A}, y^{E U}, x^{E U}\right)=\underbrace{\frac{T E_{o}^{N A}\left(y^{N A}, x^{N A}\right)}{T E_{o}^{E U}\left(y^{E U}, x^{E U}\right)}}_{T E I} \cdot \underbrace{\frac{1}{T E_{o}^{N A}\left(y^{E U}, x^{E U}\right) / T E_{o}^{E U}\left(y^{E U}, x^{E U}\right)}}_{E E I}<1
$$

Here, the Ml measures differences in environmental efficiency as the distance between the two group-specific frontiers. As a result we obtain a MI which might be smaller/larger than or equal to 1 . The $\mathrm{Ml}$ can be multiplicatively decomposed into the TEI and the EEI. The interpretation of the EEI is as follows: If we compare the efficiency of a NA with the efficiency of an EU library using the NA frontier as reference (as we use one of the library groups as the reference the nominator of the environmental efficiency index, i.e. of the latter term, is always equal

\footnotetext{
${ }^{1}$ See Førsund and Hjalmarsson (1979).
} 
to 1) an index larger than one indicates that the EU library is farther away from the NA than the EU frontier $\left(T E_{o}^{N A}\left(y^{E U}, x^{E U}\right)<T E_{o}^{E U}\left(y^{E U}, x^{E U}\right)\right)$; i.e. the NA frontier outperforms the EU frontier at the input level of the EU library under investigation.

To avoid arbitrary choices concerning the reference group we also propose to calculate the $\mathrm{MI}$ using the EU frontier as the reference, again comparing NA with EU libraries, via

$$
M I_{o}^{E U}\left(y^{N A}, x^{N A}, y^{E U}, x^{E U}\right)=\underbrace{\frac{T E_{o}^{N A}\left(y^{N A}, x^{N A}\right)}{T E_{o}^{E U}\left(y^{E U}, x^{E U}\right)}}_{T E I} \cdot \underbrace{\frac{T E_{o}^{E U}\left(y^{N A}, x^{N A}\right) / T E_{o}^{N A}\left(y^{N A}, x^{N A}\right)}{1}}_{E E I}=1,
$$

with the EEI being larger/smaller than or equal to 1 if

$$
\begin{aligned}
T E_{o}^{E U}\left(y^{N A}, x^{N A}\right) & =T E_{o}^{N A}\left(y^{N A}, x^{N A}\right) . \\
& <
\end{aligned}
$$

The NA frontier, thus, outperforms the EU frontier at the input level of the NA library under investigation if the EEI is larger than 1. Figure 1 illustrates the measurement of the distances between group-specific frontiers (i.e. the EEI) at the input level of the largest and the smallest group-specific library.

Figure 1: Measuring differences in environmental efficiency using the MI approach

3.1.2 Longitudinal analysis 
The MI introduced in (6) can also be used to analyse productivity changes over time. ${ }^{1}$ In this paper we will analyse library productivity changes between 1998 and 2004. We propose to apply the chain version ${ }^{2}$ of the Ml using 1998 as the base year. To analyse productivity changes between 1998 and 2000 we calculate

$$
\begin{aligned}
M I_{o}^{98}\left(y^{00}, x^{00}, y^{98}, x^{98}\right) & =\frac{T E_{o}^{98}\left(y^{00}, x^{00}\right)}{T E_{o}^{98}\left(y^{98}, x^{98}\right)} \\
& =\underbrace{\frac{T E_{o}^{00}\left(y^{00}, x^{00}\right)}{T E_{o}^{98}\left(y^{98}, x^{98}\right)}}_{\text {TEl }} \cdot \underbrace{\frac{T E_{o}^{98}\left(y^{00}, x^{00}\right) / T E_{o}^{00}\left(y^{00}, x^{00}\right)}{T E_{o}^{98}\left(y^{98}, x^{98}\right) / T E_{o}^{98}\left(y^{98}, x^{98}\right)}}_{\text {Techl }}
\end{aligned}
$$

while productivity changes between 2000 and 2002 (2002 and 2004) are calculated as

$$
\begin{aligned}
& M I_{o}^{98}\left(y^{02(04)}, x^{02(04)}, y^{00(02)}, x^{00(02)}\right)=\frac{T E_{o}^{98}\left(y^{02(04)}, x^{02(04)}\right)}{T E_{o}^{98}\left(y^{00(02)}, x^{00(02)}\right)}
\end{aligned}
$$

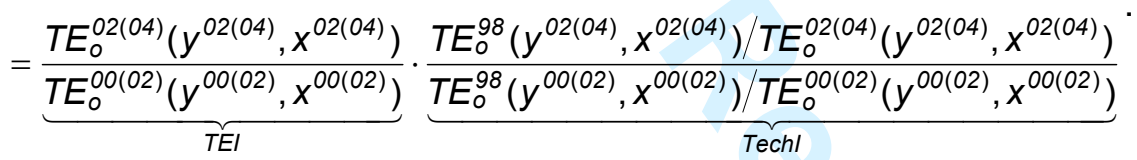

This reveals, first, that productivity changes over time may also be decomposed into an index illustrating changes in technical efficiency (TEI) and an index reflecting frontier (technology) shifts (Techl) and, second, that in (12) the latter term collapses to

$$
\frac{T E_{o}^{98}\left(y^{00}, x^{00}\right) / T E_{o}^{00}\left(y^{00}, x^{00}\right)}{1}
$$

\footnotetext{
${ }_{2}^{1}$ For the use of the Ml in longitudinal analysis see e.g. Färe et al. (1998).

${ }^{2}$ See Førsund (1993)
} 
because reference year and base year coincide. Obviously, this is not the case when any productivity change between 2000 and 2002 and 2002 and 2004 is going to be analysed. Additionally, it is possible to chain ${ }^{1}$ the indexes, i.e.

$M I_{o}^{98}\left(y^{04}, x^{04}, y^{98}, x^{98}\right)$

can be calculated as

$M I_{0}^{98}\left(y^{04}, x^{04}, y^{02}, x^{02}\right) \cdot M I_{0}^{98}\left(y^{02}, x^{02}, y^{00}, x^{00}\right) \cdot M I_{0}^{98}\left(y^{00}, x^{00}, y^{98}, x^{98}\right)$.

A Ml larger (smaller) than one therefore indicates that productivity has increased (decreased) over time, using 1998 as the base year.

\subsection{Sample, data and survey design}

\subsubsection{Sample}

In this study we aim to investigate the efficiency of university libraries, the influence of different environments on library performance and the performance changes over time. As previously indicated we defined two groups of university libraries: North American (NA) university libraries and European (EU) university libraries. The NA libraries are considered to perform against a background which can be characterised as a competitive, market-oriented environment whereas EU libraries are confronted with a higher degree of regulation. The restriction to NA university libraries as a comparison group for EU libraries is justified by the fact

\footnotetext{
${ }^{1}$ See e.g. Førsund (1993). The advantage of the chain version is that the index obeys the circular
} 
that NA libraries are considered to be the trailblazers regarding performance and performance evaluation. As representatives for the EU environment we chose Austria and Germany, as these two environments are considered to be comparable in terms of degree of regulation.

To obtain comparable libraries we decided to include libraries of similar size. Library size is measured in full-time equivalents (FTEs) of library personnel. We included only libraries with more than 90 but less than 210 FTEs. The NA university libraries were drawn from the ARL (Association of Research Libraries) database, the EU libraries from the total of German and Austrian university libraries. While the ARL administers a large amount of online accessible library data, the EU library data were collected from the public library statistics. The final sample included 68 university libraries, with $34^{1}$ EU and 34 NA university libraries. We deliberately chose the same number of libraries in the NA environment to minimise the distorting effects resulting from different model dimensions. To perform panel data analysis we collected data for the years 1998, 2000, 2002 and 2004. In case of missing or completely inconsistent data the library was not included in the performance evaluation.

\subsubsection{Data}

The library service production process is represented by the use of multiple inputs to produce several outputs. In this study, we considered the number of library employees, converted into FTEs, and the total number of book materials held (BHELD), counted in bookbinder volumes, to be reliable input proxies. FTEs

condition. 
were chosen because it turned out that library expenditure, another - possibly more suitable - candidate input measure, was barely comparable across libraries. BHELD was chosen because it is considered to be the main input with regard to one major library output, namely the utilisation of stock. Both inputs are used to fulfil the two main tasks of the library, the archival function and the utilisation function whereby the number of serial subscriptions (SER), the number of total circulations (CIRC) and the number of book materials added (BADD) are considered to be proxies for at least one or even for both of these functions. ${ }^{2}$ SER comprises the additions to serials as well as newspapers, annual reports and other journal-like series for which the library has a subscription in the relevant year. CIRC corresponds to the total number of circulations plus renewals, and BADD comprises the annual additions of book materials via buying, donation and barter. Concluding, the connection between inputs and outputs used in this study is as follows: FTEs - as already indicated - approximate material and labour expenditure and are thus considered to be the main input with regard to serial and book additions (archival services) as well as the processing, servicing and utilisation of stock (utilisation services). BHELD is the main input concerning the utilisation function as the extent of CIRC directly depends on the available stock.

Insert Table 1: Input-output statistics

There are doubtless other input and output measures that could have been employed in the analysis: the number of study seats, the number of personal computers or the number of copying machines on the input side, and the number of

\footnotetext{
${ }^{1}$ This data set comprises the total of German and Austrian university libraries with FTEs ranging from 90 to 210 FTEs.

${ }^{2}$ Apart from CIRC, the other two outputs are also related to the utilisation function as the utilisation of library services is, inter alia, directly influenced by the extent and quality of the increase in books
} 
requests processed or the extent of in-library use on the output side. While the input candidate measures are considered to be of less importance for assessing managerial efficiency, the output candidate measures are deemed much more important. As regards in-library use, some libraries report the number of persons entering the library by the number of turn-style movements; others provide data based on different survey methods (observation, random sample, count). Many libraries do not report any data concerning in-library use. With regard to total reported requests, the data are too heterogeneous to justify their use in the assessment process. Although there was no possibility of including these two outputs in the assessment because there were no data or no consistent data available, we provide some information on possible effects when we interpret the efficiency results.

\subsubsection{Survey design}

In order to assess performance differences across university libraries we now proceed as follows: First, we assess the annual technical efficiency of EU and NA university libraries separately using LP (1)-(5) and, second, we calculate differences in environmental efficiency using the Ml approach and provide some interpretation of the results (see section 4.1). Then, we apply the MI approach to analyse performance changes between 1998 and 2004 to find out whether or not there are productivity variations over time (see section 4.2).

\section{Results and analyses}

and serials, whereas the increase in stock (i.e. SER and BADD) is the only measure which also covers the archival function. 


\subsection{Cross section analysis}

Insert Table 2: TE 1998, 2000, 2002 and 2004

Overall, there does not seem to be much difference between NA and EU library performance, with 18 libraries in the EU and 20 in the NA group being inefficient in 1998. Between 2000 and 2004 however, the differences have become more marked, indicated by the constant decrease in the number of efficient libraries until 2004 in the EU group, and the decrease in the number of efficient libraries until 2002 and the subsequent increase in 2004 in the NA group. The average group-specific efficiency, represented by the efficiency of the 'average' library, is only identical in 2002 and lower in 1998, 2002 and 2004 in the NA group. Overall, from 1998 to 2004, there is a slightly negative development in both library groups, with the 'average' NA library being farther away from the NA frontier than the average EU library is away from the EU frontier.

Concerning individual libraries we found consistent results for most libraries, showing either low or consistently high productivity compared to other libraries in the prevailing reference group. Typical representatives in the EU group are, e.g., Graz, Berlin TU and Mainz with rather moderate results, and Bremen, Freiburg, Leipzig, Münster and Potsdam with constantly high results, to mention only a few. In the NA group, we have a similar picture: There are libraries with efficiency scores that are constantly high (e.g. Guelph, Manitoba, Michigan State, Oklahoma State and York), low (e.g. Brown, Delaware and Rochester), constantly increasing (e.g. Case Western Reserve and Kent State) or decreasing (e.g. California Riverside, Nebraska and Wayne State). Some libraries, however, such as 
Darmstadt, Trier, Connecticut, Florida State, George Washington or Suny-Stony Brook, show very volatile results. To provide some possible explanation we assume that the main reason for high volatility in efficiency scores is a substantial increase in journal subscriptions starting at the end of the 1990s as a result of the enormous increase in electronic journal subscriptions. The analysis of the relative importance of the input and output factors used shows that this explanation is true for Connecticut and Suny-Stony Brook. Case Western Reserve and George Washington attract attention because they are rated (almost) fully efficient in some year(s) while showing considerable inefficiencies in other years: This is due to the fact that Case Western is the smallest library in 2004 and George Washington the largest in 1998 (size measured in FTEs), a fact which results in full efficiency due to the variable RTS assumption. This means that libraries at the extreme ends of the empirically derived frontier, i.e. very small or very large libraries, might be rated fully efficient because comparable libraries of similar size are lacking. Florida State, however, is rated (almost) fully efficient in 2002 and 2004 due to the increased importance of BADD. Apart from analysing reasons for highly volatile results another point worth mentioning is that libraries with constantly low efficiency scores might be those with a high proportion of in-library use. As we were not able to take in-library use into consideration, these libraries are automatically put at a disadvantage.

Overall, the constant results for many libraries indicate substantial performance differences and identify best-practicing libraries; however, in a next step it would be worth investigating both the reasons for performance dis-/advantages as well as performance variations in more detail. 
As indicated above, the 'average' EU library performs better than the 'average' NA library, interpreted as the distance to the group-specific frontier. Whether or not the EU performance is better than the NA performance in the sense that the EU frontier outperforms the NA frontier remains to be analysed based on the environmental efficiency index. Although the NA group-specific performance seems to be slightly worse we assume that the more competitive environment in the NA group promotes productivity so that, finally, productivity in the NA group outperforms productivity in the EU group.

Insert Table 3: Environmental efficiency index

Using the NA frontier as the reference, the distance between group-specific frontiers is measured at the input level of the EU frontier. In that case, the NA frontier interestingly never outperforms the EU frontier. Only at the input level of the largest libraries and in the last two years of observation is the NA productivity as high as the EU productivity. At the input level of the smallest EU library we do not obtain any results due to the infeasibility of the LP. Infeasibility, which is also indicated graphically in Figure 1, occurs because the EU libraries have much smaller labour input levels (measured in FTEs) than the NA libraries. Figures in brackets indicate the number of FTEs of the smallest/average/largest library in Table 3. At the input level of the average EU library, the NA frontier is clearly dominated by the EU frontier in every year. At the input level of the largest EU library there is no, or just a small, productivity disadvantage.

Using the EU frontier as the reference, however, i.e. measuring frontier differences at the NA input level, we see that - except for the input level of the smallest NA library in 1998 and 2002 - the NA frontier clearly dominates the EU fron- 
tier. If we compare library size, measured in FTEs, this result indicates that the smallest/average/largest NA libraries are considerably larger than the smallest/average/largest EU libraries. In fact, the illustrative picture provided in Figure 1 approximately reflects the actual situation for the NA and the EU libraries. Consequently, we can conclude that our hypothesis that the NA frontier dominates the EU frontier is only true for higher input levels, whilst at lower input levels EU library productivity is higher than that of NA libraries.

\subsection{Longitudinal analysis}

To analyse productivity changes over time, we calculated the Ml chain version using 1998 as the base year. As we compare the productivity of each library over time using group-specific frontiers, productivity indexes are available for all libraries in the respective sample, provided input-output data are available (otherwise indicated by $n / a$ ) and the infeasibility problem does not occur (otherwise indicated by inf). Therefore, we can compare and multiplicatively decompose the productivity index of every library, i.e. we can say whether a productivity increase (decrease) is the result of an increase (decrease) in technical efficiency (TEI) and/or a positive (negative) frontier (technology) shift (Techl; see Table 4).

In the EU library group, the results indicate a productivity increase over the whole observation period, i.e. between 1998 and 2004, at the level of the average library, but a decrease between 1998 and 2000. The productivity increase of about $50 \%$ over the six-year period is exclusively due to the frontier shift of about $53 \%$ because technical efficiency slightly decreased $(-2 \%)$. One of the largest libraries (Frankfurt/M) showed a productivity decline from 1998 to 2000 of about $11 \%$ and increasing productivity of about $44 \%$ between 2000 and 2002. For Darmstadt, 
which belongs to the smallest libraries with results on the MI, we found a substantial productivity decline between 1998 and 2000, followed by a considerable increase until 2004. This increase, however, is too small to compensate the decrease from 1998 to 2000 so that we found an overall productivity decline between 1998 and 2004 of about 6\%. Overall, 18 EU libraries showed increasing productivity between 1998 and 2004. Similar to the results based on crosssection data, some findings based on longitudinal data attract considerable attention, such as the productivity increases of more than $300 \%$ for Erlangen- $\mathrm{N}$ and München. This, however, is mostly the result of a substantial increase in SER which we assume is due to the considerable increase in electronic journal subscriptions.

Similarly, the positive productivity shift of around $26 \%$ in the NA group over the six-year period at the level of the average NA library is the result of a positive frontier shift of about $28 \%$ which compensates the slight decrease in technical efficiency of approximately $2 \%$. Productivity changes could not be calculated for the smallest NA libraries, Guelph and Case Western Reserve, and the largest library in 1998, George Washington. The largest NA libraries in the other years, Boston and Michigan State, showed further productivity increases of about $22 \%$ and $38 \%$ respectively, where the productivity increases were the result of positive frontier shifts. Overall, in the NA group 21 libraries showed increasing productivity between 1998 and 2004. Concerning the time-series results for the NA group it is striking that productivity changes are altogether in a considerable range. This is in contrast to the EU results where we partly found extraordinary productivity increases. We therefore assume that, among others, libraries in the NA group do not face count problems in association with electronic journal subscriptions. Productivity declines are, similar to those in the EU group, comparably moderate. 
Insert Table 4: Productivity changes 1998-2004 (Chain version of MI with base year=1998)

\section{Limitations and outlook}

Performance measurement in any field is considered to be the impetus for performance improvement. Performance measurement using DEA is able to highlight such productivity advantages. If the purpose is to investigate productivity differences to learn from best practice, DEA is considered to be a useful tool.

Using DEA we chose a two-input and three-output variable returns-to-scale model to assess the output-oriented efficiency of university libraries of different countries. To highlight the fact that performance differences might be the result not only of managerial decisions but also of environmental influences and that performance might change over time, we applied the Malmquist index approach to address these issues. First, we calculated technical efficiency to highlight managerially-induced performance differences and then we applied the Malmquist index to investigate performance differences between European and North American libraries - measured as the distance between the European and the North American best-practice frontier. This was done as we expected that the more competitive North American environment promotes productivity. Analysing productivity differences at the input levels of the smallest, average and largest respective libraries we found that this hypothesis is definitely true for higher but not for lower input levels. Regarding the analysis of performance changes over time we mostly found productivity increases in both library groups which are 
again mostly due to frontier shifts rather than increases in technical efficiency. The largest North American libraries were still able to improve productivity whereas the smallest European libraries failed on that score.

Overall, we conclude that although we found consistent results for many libraries there are still several questions which remain unanswered: One question is whether or not libraries with a high proportion of in-library use are really being considerable disadvantaged as there was no possibility of including an output covering this part of library performance. Another question is whether or not libraries at the extreme ends of the production possibility set are only rated efficient because other libraries of similar size are missing. And, finally, especially in the EU group, there seem to be some inconsistencies concerning the count of electronic journal subscriptions for some libraries, which results in seemingly high productivity improvements. To address these questions in depth is considered to be a challenge for subsequent research. 
References

Banker, R. and Morey, R. (1986a) Efficiency analysis for exogenously fixed inputs and outputs, Operations Research, 34, 513-21.

Banker, R. and Morey, R. (1986b) The use of categorical variables in data envelopment analysis, Management Science, 32, 1613-27.

Banker, R., Charnes, A. and Cooper, W. (1984) Some models for estimating technological and scale inefficiencies in data envelopment analysis, Management Science, 30, 1078-93.

Berg, S., Førsund, F., Hjalmarsson, L. and Suominen, M. (1993) Banking efficiency in the Nordic countries, Journal of Banking and Finance, 17, 371-88.

Berghaus-Sprengel, A. (2001) Der Betriebsvergleich als Instrument der Leistungsmessung in Öffentlichen Bibliotheken, Bibliothek Forschung und Praxis, 25, 143-91.

Brophy, P. (1989) Performance measurement in academic libraries: a polytechnic perspective, British Journal of Academic Librarianship, 4, Issue 2, 99-110.

Ceynowa, K. (2001) Bibliothekscontrolling mit der Balanced Scorecard, Zeitschrift für Bibliothekswesen und Bibliographie, 48, Issue 1, 3-13.

Charnes, A., Cooper, W. and Rhodes, E. (1978) Measuring the efficiency of decision making units, European Journal of Operational Research, 2, 429-44.

Charnes, A., Cooper, W. and Rhodes, E. (1981) Evaluating program and managerial efficiency: an application of data envelopment analysis to program follow through, Management Science, 27, 668-97.

Chen, T. (1997) An evaluation of the relative performance of university libraries in Taipei, Library Review, 46, Issue 3, 190-200.

Coelli, T., Rao, P. and Battese, G. (1999) An Introduction to Efficiency and Productivity Analysis, Kluwer Academic Publishers, Dordrecht. 
Cook, W. and Zhu, J. (2005) Modelling performance measurement, Springer, New York.

Cooper, W., Seiford, L. and Tone, K. (2000) Data Envelopment Analysis. A Comprehensive Text with Models, Applications, References and DEA-Solver Software, Kluwer Academic Publishers, Boston, Dordrecht and London.

Crawford, J., Pickering, H. and McLelland, D. (1998) The Stakeholder Approach to the Construction of Performance-Measures, Journal of Librarianship and Information Science, 30, 87-112.

Färe, R., Grosskopf, S. and Roos, P. (1998) Malmquist productivity indexes: a survey of theory and practice, in: Index numbers: essays in honour of Sten Malmquist, ed. Färe, R., Grosskopf, S. and Russel, R., Kluwer Academic Publishers, Dordrecht, pp. 127-90.

Färe, R., Grosskopf, S., Lindgren, B. and Roos, P. (1992) Productivity changes in Swedish pharmacies 1980-1989: a non-parametric approach, Journal of Productivity Analysis, 3, 85-101.

Farrell, M. (1957) The measurement of productive efficiency, Journal of the Royal Statistical Society, 120, 253-81.

Fischer, T., Becker, S. and Gerke, S. (2003) Benchmarking, Die Betriebswirtschaft, 63, Issue 6, 684-701.

Fizel, J. and Nunnikhoven, T. (1993) The efficiency of nursing home chains, Applied Economics, 25, 49-55.

Førsund, F. (1993) Productivity growth in Norwegian ferries, in: The Measurement of Productive Efficiency, ed. Fried, H., Lovell, C. and Schmidt, S., Oxford University Press, New York and Oxford, pp. 352-73.

Førsund, F. and Hjalmarsson, L. (1979) Generalised Farrell measures of efficiency: an application to milk processing in Swedish dairy plants, The Economic Journal, 89, 294-315. 
Fried, H., Lovell, C. and Schmidt, S. (1993) The Measurement of Productive Efficiency - Techniques and Applications, Oxford University Press, Oxford.

Fried, H., Lovell, C., Schmidt, S. and Yaisawarng, S. (2002) Accounting for Environmental Effects and Statistical Noise in Data Envelopment Analysis, Journal of Productivity Analysis, 17, 157-74.

Glass, J., McKillop, D. and O'Rourke, G. (1998) A Cost Indirect Evaluation of Productivity Change in UK Universities, Journal of Productivity Analysis, 10, 15375.

Grosskopf, S., Self, S. and Zaim, O. (2006) Estimating the efficiency of healthcare financing in achieving better health, Applied Economics, 38, 1477-88.

Hammond, C. (2002) Efficiency in the provision of public services: a data envelopment analysis of UK public library systems, Applied Economics, 34, 649-57.

Hemmeter, J. (2006) Estimating Public Library Efficiency using Stochastic Frontiers, Public Finance Review, 34, 328-48.

Kao, C. and Lin, Y. (1999) Comparing university libraries of different university size, Libri, 49, 150-58.

Kao, C. and Liu, S. (2000) Data envelopment analysis with missing data: an application to University Libraries in Taiwan, Journal of the Operational Research Society, 51, 897-905.

Malmquist, S. (1953) Index numbers and indifference surfaces, Trabajos de Estadistica, 4, 209-42.

Mizala, A., Romaguera, P. and Farren, D. (2002) The technical efficiency of schools in Chile, Applied Economics, 34, 1533-1552.

Moore, N. (1989) Measuring the performance of public libraries - A draft manual, UNESCO, Paris. 
Mundt, S. and Guschker, S. (2003) Benchmarking als Ansatz für kundenorientierte Verbesserungsprozesse, B.I.T. online, 6, Issue 1 (http://www.bi-t-online.de/index.htm)), 37-42.

Ouellette, P. and Vierstraete, V. (2005) An evaluation of the efficiency of Quebec's school boards using Data Envelopment Analysis, Applied Economics, 37, 1643-53.

Poll, R. and Boekhorst, P. (1996) Measuring quality - International guidelines for performance measurement in academic libraries, Saur, Munich.

Reichmann, G. (2004) Measuring University Library Efficiency using Data Envelopment Analysis, Libri, 54, Issue 2, 136-46.

Reichmann, G. and Sommersguter-Reichmann, M. (2006) University library benchmarking: An international comparison using DEA, International Journal of Production Economics, 100, 131-47.

Saunders, E. (2003) Cost efficiency in ARL academic libraries, The Bottom Line: Managing library finances, 16, 5-14.

Shim, W. (2000) Assessing technical efficiency of research libraries, Advances in Library Administration and Organisation, 17, 243-339.

Shim, W. (2003) Applying DEA Technique to Library Evaluation in Academic Research Libraries, Library Trends, 51, 312-32.

Shim, W. and Kantor, P. (1998) A novel economic approach to the evaluation of academic research libraries, Proceedings of the ASIS annual meeting 1998, American Society for Information Science, Washington, 400-10.

Smith, P. and Street, A. (2005) Measuring the efficiency of public services: the limits of analysis, Journal of the Royal Statistical Society, 168, 401-17.

Thanassoulis, E. (2001) Introduction to the Theory and Application of Data Envelopment Analysis - A Foundation Text with Integrated Software, Kluwer Academic Publishers, Dordrecht. 
Van House, N., Weil, B. and McClure, C. (1990) Measuring Academic Library Performance - A practical approach, American Library Association, Chicago and London.

Vitaliano, D. (1998) Assessing Public Library Efficiency Using Data Envelopment Analysis, Annals of Public and Cooperative Economics, 69, 107-22.

Worthington, A. (1999) Performance Indicators and Efficiency Measurement in Public Libraries, The Australian Economic Review, 32, 31-42.

Worthington, A. and Dollery, B. (2002) Incorporating contextual information in public sector efficiency analyses: a comparative study of NSW local government, Applied Economics, 34, 453-464.

Zhu, J. (2003) Quantitative Models for Performance Evaluation and Benchmarking, Kluwer Academic Publishers, Boston, Dordrecht and London. 


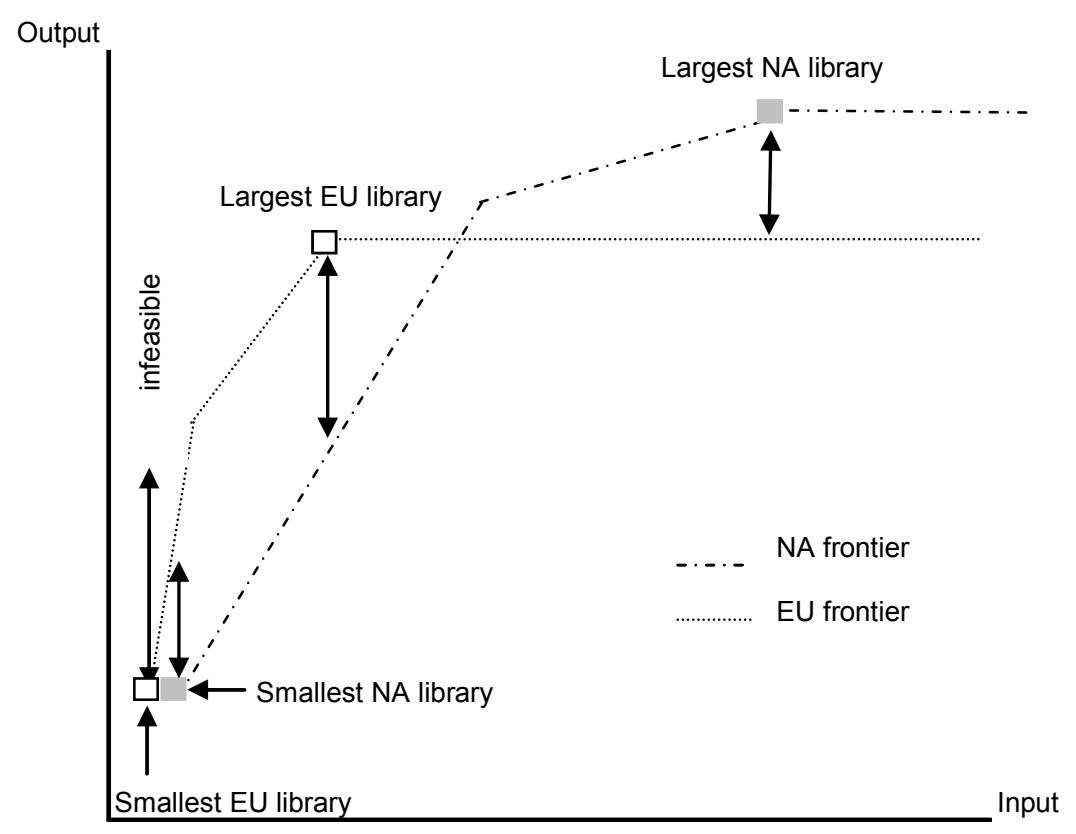

Figure 1: Measuring differences in environmental efficiency using the MI approach 


\begin{tabular}{|c|c|c|c|c|c|}
\hline & FTE & BHELD & BADD & SER & CIRC \\
\hline EU & & & 1998 & & \\
\hline Mean & 126.91 & $2,188,666.26$ & $43,082.35$ & $6,662.85$ & $674,862.56$ \\
\hline Std.Dev. & 28.62 & $761,399.66$ & $15,890.64$ & $2,359.07$ & $404,231.63$ \\
\hline Max & 188.44 & $4,687,202.00$ & $95,932.00$ & $13,702.00$ & $1,771,875.00$ \\
\hline Min & 92.50 & $928,563.00$ & $\begin{array}{l}20,529.00 \\
2000\end{array}$ & $3,399.00$ & $129,150.00$ \\
\hline Mean & 126.63 & $2,299,458.00$ & $37,511.77$ & $6,780.81$ & $628,212.06$ \\
\hline Std.Dev. & 27.58 & $780,136.88$ & $15,677.58$ & $2,299.04$ & $339,917.76$ \\
\hline Max & 189.00 & $4,828,239.00$ & $76,911.00$ & $12,476.00$ & $1,609,237.00$ \\
\hline Min & 94.70 & $1,012,324.00$ & $\begin{array}{l}5,849.00 \\
2002\end{array}$ & $3,106.00$ & $178,847.00$ \\
\hline Mean & 124.06 & $2,243,095.21$ & $35,504.21$ & $9,423.06$ & $680,987.97$ \\
\hline Std.Dev. & 27.16 & $807,790.06$ & $11,219.31$ & $3,574.77$ & $349,725.38$ \\
\hline $\operatorname{Max}$ & 191.50 & $4,956,655.00$ & $62,273.00$ & $19,687.00$ & $1,713,152.00$ \\
\hline Min & 92.50 & $920,997.00$ & $\begin{array}{l}15,786.00 \\
2004\end{array}$ & $4,322.00$ & $217,198.00$ \\
\hline Mean & 122.24 & $2,576,980.07$ & $33,382.32$ & $12,219.89$ & $771,310.46$ \\
\hline Std.Dev. & 28.64 & $983,824.68$ & $12,897.14$ & $6,185.97$ & $406,356.91$ \\
\hline $\operatorname{Max}$ & 185.00 & $5,917,038.00$ & $77,585.00$ & $26,918.00$ & $1,940,703.00$ \\
\hline Min & 91.70 & $1,113,193.00$ & $15,927.00$ & $3,406.00$ & $274,570.00$ \\
\hline NA & & & 1998 & & \\
\hline Mean & 162.38 & $2,367,618.41$ & $55,560.76$ & $17,119.32$ & $456,497.09$ \\
\hline Std.Dev. & 27.94 & $499,999.36$ & $18,431.59$ & $5,566.79$ & $205,635.08$ \\
\hline Max & 209.00 & $4,188,141.00$ & $110,296.00$ & $28,172.00$ & $1,028,805.00$ \\
\hline Min & 117.00 & $1,784,395.00$ & $\begin{array}{l}29,459.00 \\
2000\end{array}$ & $8,156.00$ & $179,170.00$ \\
\hline Mean & 162.58 & $2,475,304.45$ & $54,418.10$ & $18,209.81$ & $433,376.68$ \\
\hline Std.Dev. & 26.58 & $537,648.59$ & $16,705.53$ & $6,095.76$ & $219,931.98$ \\
\hline Max & 207.00 & $4,359,752.00$ & $95,708.00$ & $30,689.00$ & $1,006,590.00$ \\
\hline Min & 110.00 & $1,806,683.00$ & $\begin{array}{l}26,007.00 \\
2002\end{array}$ & $7,995.00$ & $164,645.00$ \\
\hline Mean & 161.59 & $2,551,086.00$ & $54,222.94$ & $21,667.29$ & $382,771.68$ \\
\hline Std.Dev. & 28.44 & $553,700.55$ & $16,720.70$ & $6,774.57$ & $222,530.07$ \\
\hline Max & 207.00 & $4,503,950.00$ & $95,548.00$ & $35,263.00$ & $1,049,580.00$ \\
\hline Min & 113.00 & $1,531,281.00$ & $\begin{array}{l}21,755.00 \\
2004\end{array}$ & $9,865.00$ & $74,525.00$ \\
\hline Mean & 156.28 & $2,682,847.75$ & $50,504.22$ & $24,538.56$ & $426,697.72$ \\
\hline Std.Dev. & 27.58 & $613,544.62$ & $15,471.45$ & $9,117.65$ & $230,356.01$ \\
\hline $\operatorname{Max}$ & 204.00 & $4,747,959.00$ & $92,637.00$ & $41,608.00$ & $1,089,986.00$ \\
\hline Min & 113.00 & $1,555,385.00$ & $26,551.00$ & $10,122.00$ & $81,035.00$ \\
\hline
\end{tabular}

Table 1: Input-output statistics 
Technical efficiency

\begin{tabular}{|c|c|c|c|c|c|c|c|c|c|}
\hline & & & & & . & & & & \\
\hline & 1998 & 2000 & 2002 & 2004 & & 1998 & 2000 & 2002 & 2004 \\
\hline EU libraries & & & & & NA libraries & & & & \\
\hline Aachen & 0,85 & 1,00 & 0,96 & 0,81 & Boston & 1,00 & 1,00 & 0,93 & 0,97 \\
\hline Augsburg & 0,96 & 0,94 & 0,99 & 0,92 & Brown & 0,56 & 0,63 & 0,74 & 0,55 \\
\hline Berlin FU & 0,69 & 0,82 & 0,79 & 0,82 & California Riverside & 1,00 & 1,00 & 0,96 & 0,87 \\
\hline Berlin TU & 0,79 & 0,77 & 0,58 & 0,49 & California Santa Barbara & 1,00 & $\mathrm{n} / \mathrm{a}$ & 0,74 & 0,95 \\
\hline Bielefeld & 1,00 & 0,96 & 0,93 & 0,83 & Case Western Reserve & 0,61 & 0,67 & 0,68 & 1,00 \\
\hline Bonn & 0,88 & 0,89 & 0,73 & 0,68 & Colorado & 1,00 & 1,00 & 0,95 & 1,00 \\
\hline Bremen & 1,00 & 1,00 & 1,00 & 1,00 & Connecticut & 0,74 & 0,70 & 1,00 & 0,90 \\
\hline Darmstadt & 1,00 & 1,00 & 0,57 & 0,63 & Delaware & 0,62 & 0,60 & 0,61 & 0,53 \\
\hline Dortmund & 1,00 & 0,83 & 0,82 & 0,94 & Florida State & 0,70 & 0,62 & 0,99 & 1,00 \\
\hline Düsseldorf & 0,79 & $\mathrm{n} / \mathrm{a}$ & 0,82 & 0,84 & George Washington & 0,98 & $\mathrm{n} / \mathrm{a}$ & 0,68 & $\mathrm{n} / \mathrm{a}$ \\
\hline Erlangen-N & 0,63 & 0,65 & 0,80 & 1,00 & Guelph & 1,00 & 1,00 & 1,00 & 1,00 \\
\hline Frankfurt/M & 0,82 & 0,76 & 0,94 & $\mathrm{n} / \mathrm{a}$ & Howard & 0,63 & 0,69 & 0,48 & 0,80 \\
\hline Freiburg & 1,00 & 1,00 & 1,00 & 1,00 & lowa State & 0,89 & 0,81 & 0,93 & 0,88 \\
\hline Graz & 0,73 & 0,85 & 0,72 & $\mathrm{n} / \mathrm{a}$ & Kent State & 0,85 & 0,86 & 0,86 & 0,97 \\
\hline Greifswald & 0,79 & 0,81 & 0,68 & $\mathrm{n} / \mathrm{a}$ & McMaster & 1,00 & 0,81 & 0,83 & 0,92 \\
\hline Innsbruck & 1,00 & 0,96 & 0,89 & 0,84 & Manitoba & 1,00 & 1,00 & 1,00 & 1,00 \\
\hline Jena & 1,00 & 0,86 & 0,97 & 0,79 & MIT & 0,70 & 0,76 & 0,72 & 0,68 \\
\hline Kassel & 1,00 & 1,00 & 0,86 & $1,00^{*}$ & Michigan State & 1,00 & 1,00 & 1,00 & 1,00 \\
\hline Kiel & 1,00 & 1,00 & 1,00 & 0,97 & Missouri & 0,84 & 0,73 & 0,54 & 0,70 \\
\hline Konstanz & 0,89 & 1,00 & 0,79 & 0,84 & Nebraska & 0,88 & 0,83 & 0,76 & 0,76 \\
\hline Köln & 1,00 & $1,00^{*}$ & 0,82 & 0,90 & Oklahoma State & 1,00 & 1,00 & 1,00 & 1,00 \\
\hline Leipzig & 1,00 & 1,00 & 1,00 & 1,00 & Queen's & 0,63 & 0,75 & 0,71 & 0,80 \\
\hline Mainz & 0,66 & 0,53 & 0,68 & 0,58 & Rice & 1,00 & $\mathrm{n} / \mathrm{a}$ & 1,00 & 1,00 \\
\hline Mannheim & 1,00 & $\mathrm{n} / \mathrm{a}$ & 1,00 & 1,00 & Rochester & 0,53 & 0,59 & 0,69 & 0,56 \\
\hline München & 0,91 & 1,00 & 0,99 & 1,00 & South Carolina & 0,83 & 1,00 & 0,94 & 1,00 \\
\hline München TU & 0,85 & $\mathrm{n} / \mathrm{a}$ & 1,00 & $\mathrm{n} / \mathrm{a}$ & SUNY-Albany & 1,00 & 0,82 & 1,00 & 1,00 \\
\hline Münster & 1,00 & 1,00 & 1,00 & 1,00 & SUNY-Stony Brook & 0,68 & 1,00 & 0,98 & 1,00 \\
\hline Potsdam & 1,00 & 1,00 & 1,00 & 1,00 & Temple & 0,68 & 0,60 & 0,71 & 0,61 \\
\hline Regensburg & 0,86 & 1,00 & 1,00 & 0,90 & Texas Tech & 1,00 & 0,98 & 1,00 & $\mathrm{n} / \mathrm{a}$ \\
\hline Rostock & 0,81 & 0,99 & 1,00 & $\mathrm{n} / \mathrm{a}$ & Tulane & 0,64 & 0,62 & 0,61 & 0,74 \\
\hline Saarbrücken & 0,98 & 1,00 & 1,00 & 1,00 & Virginia Tech & 0,93 & 0,91 & 0,83 & 0,90 \\
\hline Salzburg & 1,00 & 1,00 & 0,80 & 0,83 & Washington State & 1,00 & 1,00 & 1,00 & 0,94 \\
\hline Trier & 1,00 & 1,00 & 0,74 & 1,00 & Wayne State & 0,87 & 0,62 & 0,64 & 0,52 \\
\hline Würzburg & 0,68 & 0,73 & 0,99 & $n / a$ & York & 1,00 & 1,00 & 1,00 & 1,00 \\
\hline 'Average' library & 0,77 & 0,73 & 0,76 & 0,76 & 'Average' library & 0,73 & 0,72 & 0,76 & 0,71 \\
\hline No. Efficient & 16 & 15 & 11 & 10 & No. Efficient & 14 & 11 & 10 & 12 \\
\hline $\ln \%$ & 47 & 48 & 32 & 36 & $\ln \%$ & 41 & 35 & 29 & 38 \\
\hline * rounded up & & & & & & & & & \\
\hline TU...T & & & & & & & & & \\
\hline FU...Free univer & & & & & & & & & \\
\hline
\end{tabular}

Table 2: TE 1998, 2000, 2002 and 2004 


\begin{tabular}{|c|c|c|c|c|}
\hline & 1998 & 2000 & 2002 & 2004 \\
\hline & \multicolumn{4}{|c|}{ Reference frontier $=\mathrm{NA}$} \\
\hline $\begin{array}{l}\text { Library (EU input } \\
\text { level) }\end{array}$ & \multicolumn{4}{|c|}{$\begin{array}{c}\text { EEI } \\
\text { (FTEs) }\end{array}$} \\
\hline Smallest & $\begin{array}{c}\text { infeasible } \\
(93)\end{array}$ & $\begin{array}{c}\text { infeasible } \\
(95)\end{array}$ & $\begin{array}{c}\text { infeasible } \\
(93)\end{array}$ & $\begin{array}{c}\text { infeasible } \\
(92)\end{array}$ \\
\hline Average & $\begin{array}{c}0.66 \\
(127)\end{array}$ & $\begin{array}{c}0.53 \\
(127)\end{array}$ & $\begin{array}{c}0.59 \\
(124)\end{array}$ & $\begin{array}{c}0.50 \\
(122)\end{array}$ \\
\hline Largest & $\begin{array}{c}0.95 \\
(188)\end{array}$ & $\begin{array}{c}0.94 \\
(189)\end{array}$ & $\begin{array}{l}1.00 \\
(192)\end{array}$ & $\begin{array}{l}1.00 \\
(185)\end{array}$ \\
\hline & \multicolumn{4}{|c|}{ Reference frontier $=\mathrm{EU}$} \\
\hline $\begin{array}{l}\text { Library (NA input } \\
\text { level) }\end{array}$ & \multicolumn{4}{|c|}{$\begin{array}{c}\text { EEI } \\
\text { (FTEs) }\end{array}$} \\
\hline Smallest & $\begin{array}{c}0.83 \\
(117)\end{array}$ & $\begin{array}{l}2.74 \\
(110)\end{array}$ & $\begin{array}{l}0.79 \\
(113)\end{array}$ & $\begin{array}{l}1.03 \\
(113)\end{array}$ \\
\hline Average & $\begin{array}{l}2.05 \\
(162)\end{array}$ & $\begin{array}{l}2.33 \\
(163)\end{array}$ & $\begin{array}{c}1.73 \\
(162)\end{array}$ & $\begin{array}{c}1.76 \\
(156)\end{array}$ \\
\hline Largest & $\begin{array}{c}1.73 \\
(209)\end{array}$ & $\begin{array}{c}3.10 \\
(207)\end{array}$ & $\begin{array}{c}1.90 \\
(207)\end{array}$ & $\begin{array}{c}1.45 \\
(204)\end{array}$ \\
\hline
\end{tabular}

Table 3: Environmental efficiency index 


\begin{tabular}{|c|c|c|c|c|c|c|c|c|c|c|c|c|}
\hline & \multicolumn{3}{|c|}{$98 / 00$} & \multicolumn{3}{|c|}{$00 / 02$} & \multicolumn{3}{|c|}{$02 / 04$} & \multicolumn{3}{|c|}{ 98/04 } \\
\hline EU libraries & TEI & Techl & $\mathrm{Ml}$ & TEI & Techl & MI & TEI & Techl & MI & TEI & Techl & MI \\
\hline Aachen & 1.17 & 1.14 & 1.33 & 0.96 & 1.18 & 1.14 & 0.84 & 0.73 & 0.62 & 0.95 & 0.99 & 0.94 \\
\hline Augsburg & 0.98 & 0.92 & 0.90 & 1.05 & 2.39 & 2.51 & 0.93 & 1.30 & 1.22 & 0.96 & 2.88 & 2.76 \\
\hline Berlin FU & 1.17 & 1.02 & 1.19 & 0.97 & 1.09 & 1.06 & 1.03 & 1.55 & 1.60 & 1.18 & 1.72 & 2.02 \\
\hline Berlin TU & 0.97 & 1.00 & 0.97 & 0.76 & 1.29 & 0.98 & 0.85 & 1.06 & 0.91 & 0.63 & 1.38 & 0.86 \\
\hline Bielefeld & 0.96 & 0.95 & 0.91 & 0.96 & 1.49 & 1.43 & 0.90 & 0.73 & 0.66 & 0.83 & 1.03 & 0.86 \\
\hline Bonn & 1.01 & 0.98 & 0.99 & 0.82 & 1.40 & 1.15 & 0.93 & 1.07 & 0.99 & 0.78 & 1.46 & 1.13 \\
\hline Bremen & 1.00 & 1.11 & 1.11 & 1.00 & 1.22 & 1.22 & 1.00 & 0.98 & 0.98 & 1.00 & 1.32 & 1.32 \\
\hline Darmstadt & 1.00 & 0.67 & 0.67 & 0.57 & 2.15 & 1.23 & 1.10 & 1.04 & 1.14 & 0.63 & 1.50 & 0.94 \\
\hline Dortmund & 0.83 & 0.83 & 0.69 & 0.99 & 1.54 & 1.53 & 1.14 & 1.26 & 1.45 & 0.94 & 1.62 & 1.53 \\
\hline Düsseldorf & $\mathrm{n} / \mathrm{a}$ & $\mathrm{n} / \mathrm{a}$ & $\mathrm{n} / \mathrm{a}$ & $\mathrm{n} / \mathrm{a}$ & $n / a$ & $\mathrm{n} / \mathrm{a}$ & 1.03 & 0.99 & $\mathrm{n} / \mathrm{a}$ & 1.06 & 1.19 & 1.26 \\
\hline Erlangen-N & 1.03 & 0.99 & 1.03 & 1.23 & 1.00 & 1.23 & 1.25 & 1.98 & 2.48 & 1.59 & 1.96 & 3.13 \\
\hline Frankfurt/M & 0.93 & 0.96 & 0.89 & 1.24 & 1.17 & 1.44 & $\mathrm{n} / \mathrm{a}$ & $\mathrm{n} / \mathrm{a}$ & $\mathrm{n} / \mathrm{a}$ & $\mathrm{n} / \mathrm{a}$ & $\mathrm{n} / \mathrm{a}$ & $\mathrm{n} / \mathrm{a}$ \\
\hline Freiburg & 1.00 & 1.00 & 1.00 & 1.00 & 1.00 & 1.00 & 1.00 & 1.13 & 1.13 & 1.00 & 1.12 & 1.12 \\
\hline Graz & 1.18 & 0.94 & 1.11 & 0.85 & 0.96 & 0.81 & $\mathrm{n} / \mathrm{a}$ & $n / a$ & $\mathrm{n} / \mathrm{a}$ & $\mathrm{n} / \mathrm{a}$ & $\mathrm{n} / \mathrm{a}$ & $\mathrm{n} / \mathrm{a}$ \\
\hline Greifswald & 1.03 & 0.82 & 0.84 & 0.84 & 1.56 & 1.32 & $\mathrm{n} / \mathrm{a}$ & $n / a$ & $\mathrm{n} / \mathrm{a}$ & $\mathrm{n} / \mathrm{a}$ & $n / a$ & $\mathrm{n} / \mathrm{a}$ \\
\hline Innsbruck & 0.96 & 0.90 & 0.87 & 0.92 & 1.02 & 0.94 & 0.95 & 1.07 & 1.01 & 0.84 & 0.98 & 0.83 \\
\hline Jena & 0.86 & 1.00 & 0.85 & 1.13 & 0.95 & 1.07 & 0.82 & 1.17 & 0.95 & 0.79 & 1.10 & 0.87 \\
\hline Kassel & 1.00 & 1.17 & 1.17 & 0.86 & 0.87 & 0.75 & 1.16 & 1.10 & 1.27 & 1.00 & 1.12 & 1.12 \\
\hline Kiel & 1.00 & 0.93 & 0.93 & 1.00 & 1.31 & 1.31 & 0.97 & 1.64 & 1.60 & 0.97 & 2.00 & 1.95 \\
\hline Konstanz & 1.12 & 0.88 & 0.99 & 0.79 & 1.71 & 1.35 & 1.06 & 1.49 & 1.58 & 0.94 & 2.25 & 2.11 \\
\hline Köln & 1.00 & 0.88 & 0.88 & 0.82 & 1.23 & 1.00 & 1.11 & 1.45 & 1.60 & 0.90 & 1.56 & 1.41 \\
\hline Leipzig & 1.00 & 0.97 & 0.97 & 1.00 & 1.11 & 1.11 & 1.00 & 1.66 & 1.66 & 1.00 & 1.79 & 1.79 \\
\hline Mainz & 0.81 & 0.86 & 0.70 & 1.27 & 1.99 & 2.53 & 0.86 & 1.19 & 1.03 & 0.89 & 2.05 & 1.82 \\
\hline Mannheim & $\mathrm{n} / \mathrm{a}$ & $\mathrm{n} / \mathrm{a}$ & $\mathrm{n} / \mathrm{a}$ & $\mathrm{n} / \mathrm{a}$ & $n / a$ & $\mathrm{n} / \mathrm{a}$ & 1.00 & inf & $\mathrm{n} / \mathrm{a}$ & 1.00 & inf & $\mathrm{n} / \mathrm{a}$ \\
\hline München & 1.09 & 1.04 & 1.13 & 0.99 & 1.40 & 1.39 & 1.01 & 1.96 & 1.97 & 1.09 & 2.85 & 3.12 \\
\hline München TU & $\mathrm{n} / \mathrm{a}$ & $\mathrm{n} / \mathrm{a}$ & $\mathrm{n} / \mathrm{a}$ & $\mathrm{n} / \mathrm{a}$ & inf & inf & $\mathrm{n} / \mathrm{a}$ & $\mathrm{n} / \mathrm{a}$ & $\mathrm{n} / \mathrm{a}$ & $\mathrm{n} / \mathrm{a}$ & $\mathrm{n} / \mathrm{a}$ & $\mathrm{n} / \mathrm{a}$ \\
\hline Münster & 1.00 & 1.03 & 1.03 & 1.00 & 1.11 & 1.11 & 1.00 & 1.41 & 1.41 & 1.00 & 1.61 & 1.61 \\
\hline Potsdam & 1.00 & 1.12 & 1.12 & 1.00 & inf & inf & 1.00 & inf & inf & 1.00 & inf & $\inf$ \\
\hline Regensburg & 1.17 & 0.92 & 1.07 & 1.00 & 1.18 & 1.18 & 0.90 & 1.57 & 1.41 & 1.05 & 1.70 & 1.79 \\
\hline Rostock & 1.23 & 0.78 & 0.96 & 1.01 & 1.09 & 1.10 & $\mathrm{n} / \mathrm{a}$ & $n / a$ & $\mathrm{n} / \mathrm{a}$ & $\mathrm{n} / \mathrm{a}$ & $\mathrm{n} / \mathrm{a}$ & $\mathrm{n} / \mathrm{a}$ \\
\hline Saarbrücken & 1.03 & 0.97 & 0.99 & 1.00 & 3.03 & 3.03 & 1.00 & inf & inf & 1.03 & inf & inf \\
\hline Salzburg & 1.00 & 0.83 & 0.83 & 0.80 & 1.21 & 0.97 & 1.04 & 0.94 & 0.98 & 0.83 & 0.95 & 0.79 \\
\hline Trier & 1.00 & 0.91 & 0.91 & 0.74 & 1.78 & 1.31 & 1.35 & 0.76 & 1.03 & 1.00 & 1.23 & 1.23 \\
\hline Würzburg & 1.07 & 0.91 & 0.97 & 1.36 & 2.41 & 3.28 & $\mathrm{n} / \mathrm{a}$ & $\mathrm{n} / \mathrm{a}$ & $\mathrm{n} / \mathrm{a}$ & $\mathrm{n} / \mathrm{a}$ & $\mathrm{n} / \mathrm{a}$ & $\mathrm{n} / \mathrm{a}$ \\
\hline 'Average' library & 0.95 & 0.99 & 0.94 & 1.04 & 1.23 & 1.28 & 0.99 & 1.26 & 1.25 & 0.98 & 1.53 & 1.50 \\
\hline NA libraries & TEI & Techl & $\mathrm{MI}$ & TEI & Techl & MI & TEI & Techl & $\mathrm{Ml}$ & TEI & Techl & $\mathrm{Ml}$ \\
\hline Boston & 1.00 & 1.11 & 1.11 & 0.93 & 1.01 & 0.94 & 1.04 & 1.11 & 1.16 & 0.97 & 1.26 & 1.22 \\
\hline Brown & 1.13 & 0.92 & 1.04 & 1.18 & 1.10 & 1.30 & 0.73 & 1.19 & 0.87 & 0.98 & 1.20 & 1.17 \\
\hline California Riverside & 1.00 & 0.89 & 0.89 & 0.96 & 1.12 & 1.07 & 0.90 & 1.17 & 1.06 & 0.87 & 1.17 & 1.01 \\
\hline California Santa Barbara & $\mathrm{n} / \mathrm{a}$ & $\mathrm{n} / \mathrm{a}$ & $\mathrm{n} / \mathrm{a}$ & $\mathrm{n} / \mathrm{a}$ & $\mathrm{n} / \mathrm{a}$ & $\mathrm{n} / \mathrm{a}$ & 1.28 & 1.35 & 1.72 & 0.95 & 1.44 & 1.37 \\
\hline Case Western Reserve & 1.09 & 1.10 & 1.20 & 1.02 & inf & $\inf$ & 1.46 & inf & inf & 1.63 & $\inf$ & inf \\
\hline Colorado & 1.00 & 1.07 & 1.07 & 0.95 & 0.93 & 0.88 & 1.06 & 0.94 & 0.99 & 1.00 & 0.93 & 0.93 \\
\hline Conne & 0.95 & 0.96 & 0.91 & 1.42 & 1.34 & 1.90 & 0.90 & 1.18 & 1.07 & 1.22 & 1.52 & 1.85 \\
\hline Delaware & 0.98 & 0.95 & 0.93 & 1.02 & 1.00 & 1.02 & 0.87 & 1.01 & 0.87 & 0.86 & 0.95 & 0.82 \\
\hline Florida State & 0.88 & 0.98 & 0.86 & 1.61 & 0.91 & 1.46 & 1.01 & 1.54 & 1.55 & 1.42 & 1.37 & 1.94 \\
\hline George Washington & $\mathrm{n} / \mathrm{a}$ & $\mathrm{n} / \mathrm{a}$ & $\mathrm{n} / \mathrm{a}$ & $\mathrm{n} / \mathrm{a}$ & $\mathrm{n} / \mathrm{a}$ & $\mathrm{n} / \mathrm{a}$ & $\mathrm{n} / \mathrm{a}$ & $\mathrm{n} / \mathrm{a}$ & $\mathrm{n} / \mathrm{a}$ & $\mathrm{n} / \mathrm{a}$ & $n / a$ & $\mathrm{n} / \mathrm{a}$ \\
\hline Guelp & 1.00 & inf & $\inf$ & 1.00 & inf & $\inf$ & 1.00 & inf & inf & 1.00 & inf & $\inf$ \\
\hline Howard & 1.09 & 0.99 & 1.07 & 0.70 & 1.25 & 0.88 & 1.66 & 0.57 & 0.95 & 1.27 & 0.71 & 0.90 \\
\hline lowa State & 0.91 & 1.04 & 0.95 & 1.15 & 1.17 & 1.35 & 0.94 & 1.25 & 1.17 & 0.98 & 1.52 & 1.49 \\
\hline Kent State & 1.01 & 0.82 & 0.83 & 1.00 & 1.02 & 1.02 & 1.13 & 0.94 & 1.06 & 1.14 & 0.78 & 0.89 \\
\hline McMaster & 0.81 & 1.03 & 0.84 & 1.02 & 1.18 & 1.21 & 1.11 & 0.89 & 0.99 & 0.92 & 1.09 & 1.00 \\
\hline Manitoba & 1.00 & 1.43 & 1.43 & 1.00 & 0.73 & 0.73 & 1.00 & 0.96 & 0.96 & 1.00 & 1.01 & 1.01 \\
\hline MIT & 1.08 & 1.01 & 1.09 & 0.95 & 1.11 & 1.05 & 0.94 & 1.07 & 1.00 & 0.96 & 1.19 & 1.15 \\
\hline Michigan State & 1.00 & 1.04 & 1.04 & 1.00 & 1.07 & 1.07 & 1.00 & 1.24 & 1.24 & 1.00 & 1.38 & 1.38 \\
\hline Missouri & 0.87 & 1.06 & 0.93 & 0.73 & 1.02 & 0.75 & 1.30 & 0.97 & 1.26 & 0.83 & 1.05 & 0.87 \\
\hline Nebraska & 0.93 & 1.04 & 0.97 & 0.92 & 1.06 & 0.98 & 1.00 & 1.38 & 1.38 & 0.86 & 1.54 & 1.32 \\
\hline Oklahoma State & 1.00 & 1.12 & 1.12 & 1.00 & 1.02 & 1.02 & 1.00 & 1.65 & 1.65 & 1.00 & 1.90 & 1.90 \\
\hline Queen's & 1.20 & 0.94 & 1.13 & 0.95 & 1.12 & 1.06 & 1.12 & 1.02 & 1.14 & 1.28 & 1.07 & 1.37 \\
\hline Rice & $\mathrm{n} / \mathrm{a}$ & $\mathrm{n} / \mathrm{a}$ & $\mathrm{n} / \mathrm{a}$ & $\mathrm{n} / \mathrm{a}$ & $\mathrm{n} / \mathrm{a}$ & $\mathrm{n} / \mathrm{a}$ & 1.00 & inf & inf & 1.00 & 0.85 & 0.85 \\
\hline Rochester & 1.11 & 0.86 & 0.95 & 1.18 & 1.38 & 1.62 & 0.82 & 1.25 & 1.02 & 1.07 & 1.47 & 1.57 \\
\hline South Carolina & 1.20 & 0.94 & 1.12 & 0.94 & 1.03 & 0.97 & 1.06 & 1.04 & 1.10 & 1.20 & 1.00 & 1.20 \\
\hline SUNY-Albany & 0.82 & 0.99 & 0.82 & 1.22 & 1.34 & 1.63 & 1.00 & 1.23 & 1.23 & 1.00 & 1.63 & 1.63 \\
\hline SUNY-Stony Brook & 1.46 & $\inf$ & inf & 0.98 & inf & $\inf$ & 1.02 & $\inf$ & inf & 1.46 & $\inf$ & $\inf$ \\
\hline Templ & 0.87 & 1.05 & 0.92 & 1.19 & 0.98 & 1.17 & 0.86 & 1.42 & 1.22 & 0.89 & 1.47 & 1.31 \\
\hline Texas Tech & 0.98 & 1.03 & 1.02 & 1.02 & 1.14 & 1.16 & $\mathrm{n} / \mathrm{a}$ & $\mathrm{n} / \mathrm{a}$ & $\mathrm{n} / \mathrm{a}$ & $\mathrm{n} / \mathrm{a}$ & $\mathrm{n} / \mathrm{a}$ & $\mathrm{n} / \mathrm{a}$ \\
\hline Tulane & 0.96 & 1.00 & 0.96 & 0.98 & 1.04 & 1.03 & 1.22 & 0.88 & 1.08 & 1.16 & 0.93 & 1.07 \\
\hline Virginia Tech & 0.98 & 0.88 & 0.86 & 0.91 & 1.07 & 0.97 & 1.08 & 1.80 & 1.95 & 0.96 & 1.69 & 1.64 \\
\hline
\end{tabular}




\begin{tabular}{l|lll|lll|lll|lll} 
Washington State & 1.00 & 1.15 & 1.15 & 1.00 & 1.15 & 1.15 & 0.94 & 1.03 & 0.96 & 0.94 & 1.37 & 1.28 \\
Wayne State & 0.71 & 1.06 & 0.76 & 1.04 & 0.99 & 1.02 & 0.82 & 1.36 & 1.11 & 0.60 & 1.43 & 0.86 \\
York & 1.00 & 1.00 & 1.00 & 1.00 & 1.05 & 1.05 & 1.00 & 1.04 & 1.04 & 1.00 & 1.10 & 1.10 \\
\hline 'Average' library & 0.99 & 1.02 & 1.01 & 1.06 & 1.06 & 1.12 & 0.94 & 1.19 & 1.12 & 0.98 & 1.28 & 1.26 \\
\hline
\end{tabular}

Table 4: Productivity changes1998-2004

(Chain version of Ml with base year=1998) 